\title{
PEMETAAN PROFIL PASIEN/KLIEN RUMAH SAKIT UMUM DAERAH (RSUD) KOTA X MENGGUNAKAN NET PROMOTER SCORE
}

\author{
Elsa Roselina
}

Laboratorium Program Studi Perumahsakitan, Program Pendidikan Vokasi Universitas Indonesia, elsa@vokasi.ui.ac.id

Diterima : 14 November 2015

Layak Terbit : 29 Desember 2015

\begin{abstract}
Abstrak
Rumah Sakit Umum Daerah (RSUD) Kota X merupakan satu-satunya rumah sakit milik pemerintah Kota X, memiliki visi diantaranya memberikan pelayanan paripurna yang bermutu prima kepada seluruh lapisan masyarakat. Net Promoter Score (NPS) merupakan sebuah alat dan konsep kepuasan pelanggan, dimana melalui NPS perusahaan dapat mengetahui performance mereka menurut perspektif pelanggannya. Penelitian ini bertujuan untuk memperoleh gambaran profil konsumen dan mengidentifikasi kekuatan serta kelemahan pelayanan di RSUD Kota X berdasarkan persepsi konsumen. Penelitian ini menggunakan pendekatan kuantitatif dengan metode survey. Data diambil dalam satu kali pengukuran (one shoot measurement) pada bulan Agustus hingga September 2015. Instrumen yang digunakan berupa kuesioner. Subyek penelitian adalah pasien/keluarga yang menjalani pengobatan rawat jalan maupun rawat inap di beberapa ruang perawatan RSUD Kota X. Sampel berjumlah 442 orang dihitung menggunakan rumus Slovin dengan nilai alpha 0,05. Analisis yang digunakan adalah analisis univariat. Hasil akhir penelitian menunjukkan profil pasien/keluarga kebanyakan sebagai konsumen detractors $(45,2 \%)$ dibandingkan konsumen promoters $(19,7 \%)$, dimana nilai NPS lebih baik ditunjukkan oleh persepsi pasien rawat inap dibandingkan pasien rawat jalan. Kelemahan pelayanan di rawat jalan adalah sistem antrean yang lama dan keterbatasan fasilitas, sedangkan di rawat inap adalah keterbatasan fasilitas serta masalah kebersihan. Kekuatan RSUD Kota X dalam memberikan pelayanan adalah keramahan petugasnya (dokter, perawat, administrasi).
\end{abstract}

Kata kunci: net promoter score, profil konsumen, pelayanan rumah sakit

\begin{abstract}
Regional General Hospital City X is the only government-owned hospitals of city X, had some vision including provide excellent service quality plenary to the whole society. Net Promoter Score (NPS) is a tool and concept of customer satisfaction, which through NPS companies can see their performance according to the customer's perspective. This study aimed to obtain consumer profiles and identify strengths and weaknesses in the service of the Regional General Hospital City X based on the perception of consumers. This study used a quantitative approach with survey method. Data captured in one shoot measurement from August until September 2015. Instruments used in the form of a questionnaire. The research subjects were patients/families undergoing outpatient treatment or hospitalization in some treatment rooms of the Regional General Hospital City X. The total sample was 442 persons, calculated using the Slovin formula with alpha 0.05. The analysis was univariate analysis. The final results showed the profile of patients/families mostly as consumers detractors (45.2\%) than consumers promoters (19.7\%), where the value indicated by the NPS better perception of inpatients than outpatients. Weakness in outpatient services is a long queue system and the limited facilities, whereas in inpatient facilities are limited and hygiene problems. City Hospital $X$ strength in providing services is the friendliness of its officers (doctors, nurses, administration).
\end{abstract}

Keywords: net promoter score, consumer profile, hospital service 


\section{PENDAHULUAN}

Rumah Sakit berdasarkan Permenkes No. 147 tahun 2010 adalah institusi pelayanan kesehatan yang menyelenggarakan pelayanan kesehatan perorangan secara paripurna yang menyediakan pelayanan rawat inap, rawat jalan, dan gawat darurat. Sebagai salah satu industri jasa, kepuasan konsumen/klien merupakan hal yang penting. Rumah Sakit Umum Daerah (RSUD) Kota X merupakan satu-satunya Rumah Sakit milik Pemerintah yang berada di Kota X, memiliki beberapa visi, diantaranya adalah memberikan pelayanan paripurna yang bermutu prima kepada seluruh lapisan masyarakat. Motto rumah sakit ini adalah memberikan pelayanan yang CERIA - P (Cepat, Efektif, Ramah, Inovatif, Aman - Profesional). Motto tersebut dilaksanakan secara berlanjut dan menyeluruh dengan sasaran meningkatkan kepuasan pelanggan dalam hal ini adalah pasien dan keluarganya. Dalam memantau tingkat kepuasan penggunanya, RSUD Kota X melakukan survey kepuasan masyarakat, dimana hasil indeks kepuasan masyarakat yang diperoleh pada tahun 2013 adalah dalam kisaran 62,51 - 81,25, dengan kategori baik untuk kinerja unit pelayanan.

Net Promoter Score (NPS) merupakan sebuah alat dan konsep kepuasan pelanggan yang dipublikasikan oleh Fred Reichheld. Diperkenalkan pertama kali pada tahun 2003 dan metode ini telah digunakan oleh banyak perusahaan besar ternama (Reichheld, 2011). Melalui penggunaan NPS ini, perusahaan (termasuk diantaranya rumah sakit) dapat mengetahui performance mereka menurut perspektif konsumen/pelanggannya (The Net Promoter Community, 2015). Selama ini RSUD Kota X belum pernah menggunakan NPS sebagai media survei kepuasan masyarakat terhadap pelayanan yang diberikan. Berdasarkan hal tersebut, maka kami bermaksud melakukan penelitian yang berjudul pemetaan Profil Pasien/Klien RSUD Kota X menggunakan Net Promoter Score (NPS).

Penelitian ini bertujuan secara umum untuk memperoleh gambaran profil konsumen (pasien/klien) RSUD Kota X, dan secara khusus untuk mengidentifikasi kekuatan serta kelemahan pelayanan di RSUD Kota X berdasarkan persepsi konsumen. Diharapkan hasil penelitian ini akan memberi masukan terhadap RSUD Kota $\mathrm{X}$ untuk mengembangkan pelayanannya kepada masyarakat dan penelitian ini dapat menjadi dasar dalam pemanfaatan metode NPS dalam menilai pelayanan kesehatan (health services).

\section{METODE}

Penelitian ini menggunakan pendekatan kuantitatif dengan metode survey. Populasi penelitian adalah pasien maupun keluarga pasien yang berobat di RSUD Kota X. Subyek penelitian adalah pasien/keluarga yang menjalani pengobatan rawat jalan maupun rawat inap di beberapa ruang perawatan (Kebidanan, Bedah, Penyakit Dalam, Syaraf/ THT/Mata, Ruang Perawat-an Kelas II) RSUD Kota X. Pemilihan sampel dilakukan dengan quota sampling. Data diambil dalam satu kali pengukuran (one shoot measurement) 
pada bulan Agustus hingga September 2015, menggunakan kuesioner. Sampel berjumlah 442 orang (392 orang pasien rawat jalan dan 50 orang pasien rawat inap/keluarga) yang dihitung menggunakan rumus Slovin dengan nilai alpha 0,05. Pemenuhan etika penelitian dilakukan melalui proses perijinan dan paparan kegiatan penelitian yang akan dilakukan kepada pihak RSUD Kota Depok dan Kasbangpol Kota Depok. Selain itu juga dilakukan informed consent kepada subyek penelitian. Analisis statistik yang digunakan adalah analisis univariat.

\section{HASIL DAN PEMBAHASAN}

\section{Karakteristik Responden}

Sesuai dengan perhitungan sampel dalam penelitian, kebutuhan responden terdiri dari 392 orang responden rawat jalan (88,7\%) dan 50 orang responden rawat inap (11,3\%). Berikut dipaparkan gambaran dari karakteristik responden penelitian ini.

Rata-rata usia responden adalah 43,60 tahun, mayoritas berjenis kelamin perempuan (72\%), berpendidikan SMA (38\%) dan pembiayaan berobat dari BPJS Kesehatan (57\%). Hal ini dapat dilihat pada tabel 1 dan 2 .

Tabel 1. Distribusi Responden Menurut Usia $(\mathrm{N}=442)$

\begin{tabular}{ccccc}
\hline Mean & Median & SD & Min & Mak \\
\hline 43,60 & 43,00 & Variabel & 13,00 & 87,00 \\
\hline \multicolumn{5}{ll}{ Sumber: Hasil pengolahan kuesioner September 2015 }
\end{tabular}

Tabel 2. Karakteristik Responden Menurut Jenis Kelamin, Tingkat Pendidikan dan Pembiayaan Berobat $(\mathrm{N}=\mathbf{4 4 2})$

\begin{tabular}{lcc}
\hline \multicolumn{1}{c}{ Variabel } & Jumlah & Persentase \\
\hline Jenis Kelamin & & \\
Laki-laki & 112 & 28 \\
Perempuan & 320 & 72 \\
Tingkat Pendidikan & & \\
Tidak bersekolah & 11 & 2 \\
Tidak tamat SD & 13 & 3 \\
SD & 76 & 17 \\
SMP & 98 & 22 \\
SMA & 166 & 38 \\
Diploma & 38 & 9 \\
Sarjana (S1) & 34 & 8 \\
Pasca Sarjana & 6 & 1 \\
Pembiayaan Berobat & & \\
BPJS Kesehatan & 252 & 57 \\
Jamkesda & 119 & 27 \\
Asuransi Kesehatan non & & 13 \\
pemerintah & 7 & 2 \\
Biaya sendiri & 64 & 14 \\
\hline Sumber : Hasil Pengolaan Kuisioner September 2015
\end{tabular}

\section{Nilai Net Promoter Score (NPS)}

Rata-rata nilai NPS dari seluruh responden adalah 6,68, dimana rata-rata nilai NPS pada responden rawat inap adalah 6,62 dan rawat jalan 6,68, seperti yang terdapat pada tabel 3 .

Tabel 3. Distribusi Nilai NPS Berdasarkan Kategori

\begin{tabular}{cccccc}
\multicolumn{8}{c}{ Responden } \\
$\begin{array}{c}\text { Kategori } \\
\text { Responden }\end{array}$ & Mean & Median & SD & Min & Mak \\
\cline { 1 - 4 } Keseluruhan & 6,68 & 7,00 & 2,21 & 0,00 & 10,00 \\
Rawat Inap & 6,62 & 7,00 & 2,61 & 0,00 & 10,00 \\
Rawat Jalan & 6,68 & 7,00 & 2,16 & 0,00 & 10,00 \\
\hline
\end{tabular}

Sumber :Hasil pengolahan kuisioner September 2015

\section{Profil Konsumen}

Mayoritas responden memiliki profil sebagai konsumen detractors, sebanyak 200 orang $(45,2 \%)$ dan hanya sedikit pasien yang berprofil sebagai konsumen promoters. Hal ini dapat dilihat pada gambar 1 . 


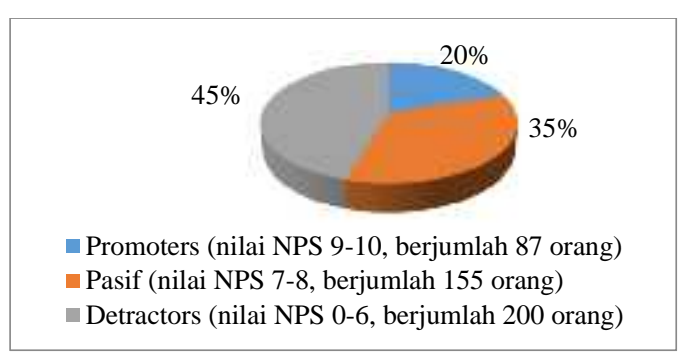

Gambar 1. Distribusi Responden Menurut Profil NPS

Berdasarkan gambar 1, pun dapat diketahui bahwa hasil perhitungan NPS RSUD Kota X $=$ persentase konsumen promoters dikurangi persentase konsumen detractors $=20 \%-45 \%$ $=-25 \%$. Hal ini semakin memperlihatkan bahwa mayoritas kategori konsumen RSUD Kota X merupakan detractors.

Proporsi responden memiliki profil sebagai konsumen detractors lebih banyak pada pasien rawat jalan $(45,7 \%)$ dibandingkan pasien rawat inap (42,0\%). Hal ini dapat dilihat pada secara rinci pada tabel 4.

Tabel 4. Distribusi Responden Menurut Profil NPS Berdasarkan Unit Perawatan

\begin{tabular}{lcccc}
\hline Kategori & \multicolumn{2}{c}{ Unit Rawat Jalan } & \multicolumn{2}{c}{ Unit Rawat Inap } \\
\cline { 2 - 5 } \multicolumn{1}{c}{ Profil } & $\mathbf{n}$ & $\mathbf{\%}$ & $\mathbf{n}$ & $\boldsymbol{\%}$ \\
\hline promoters & 75 & 19.1 & 12 & 24.0 \\
pasif & 138 & 35.2 & 17 & 34.0 \\
detractors & 179 & 45.7 & 21 & 42.0 \\
\hline Jumlah & 392 & 100.0 & 50 & 100.0 \\
\hline Sumber : Hasil pengolahan kuisioner September 2015
\end{tabular}

Tidak semua responden mengisi atau memberikan jawaban terkait dengan alasan memberikan nilai NPS. Alasan yang diberikan oleh responden yang menjawab selanjutnya dikelompokkan menjadi kekuatan serta kelemahan RSUD Kota X.

\section{Kekuatan dan Kelemahan RSUD Kota X menurut Konsumen}

Kelemahan RSUD Kota X dalam pemberian pelayanan di rawat inap adalah ketersediaan fasilitas (mushola, ac, kipas angin, penerangan ruangan) sebesar 83,3\% dan kebersihan (ruangan, kamar mandi) sebesar $80 \%$. Kekuatan RSUD Kota X dalam pemberian pelayanan di rawat inap adalah keramahan petugas (dokter, perawat, administrasi) dan kecepatan layanan BPJS, masing-masing sebesar 100\%, serta pelayanan yang baik sebesar 66,7\%. Secara lebih lengkap hal ini dapat dilihat pada tabel 5 .

Kelemahan RSUD Kota X dalam pemberian pelayanan di rawat jalan adalah sistem antrean yang dirasakan lama 100\%, ketersediaan fasilitas (mushola, ac, kipas angin, penerangan ruangan) sebesar 78,2\%, kejelasan informasi dan alur berobat 62,5\%, dan kebersihan (ruangan, kamar mandi) sebesar 50\%. Kekuatan RSUD Kota X dalam pemberian pelayanan di rawat jalan adalah keramahan petugas (dokter, perawat, administrasi) sebesar $80 \%$ dan pelayanan yang baik sebesar 78,4\%. Secara lebih lengkap hal ini dapat dilihat pada tabel 5 .

\section{Saran Konsumen bagi Pelayanan di RSUD}

\section{Kota X}

Tidak semua konsumen (responden) memberikan saran terhadap pelayanan yang diberikan oleh RSUD Kota X. Proporsi saran yang diberikan dilakukan berdasarkan persentase dari jumlah seluruh responden. 
Tabel 5. Distribusi Responden Rawat Jalan Menurut Penilaian terhadap Kekuatan dan Kelemahan RSUD Kota X

\begin{tabular}{llccccc}
\hline \multirow{2}{*}{ Aspek yang Dinilai } & \multicolumn{2}{c}{ Baik } & \multicolumn{2}{c}{ Kurang } & \multicolumn{3}{c}{$\begin{array}{c}\text { Total } \\
\text { Penjawab }\end{array}$} \\
\cline { 2 - 7 } & $\mathrm{n}$ & $\%$ & $\mathrm{n}$ & $\%$ & $\mathrm{~N}$ & $\%$ \\
\hline $\begin{array}{l}\text { Ketersediaan fasilitas (mushola, ac, kipas angin, penerangan } \\
\text { ruangan) }\end{array}$ & 19 & 21,8 & 68 & 78,2 & 87 & 100,0 \\
Kebersihan ruangan, kamar mandi & 14 & 50,0 & 14 & 50,0 & 28 & 100,0 \\
Pelayanan & 149 & 78,4 & 41 & 21,6 & 190 & 100,0 \\
Keramahan petugas (dokter, perawat, administrasi) & 48 & 80,0 & 12 & 20,0 & 60 & 100,0 \\
Sistem antrean & - & - & 98 & 100,0 & 98 & 100,0 \\
Kejelasan informasi dan alur berobat & 9 & 37,5 & 15 & 62,5 & 24 & 100,0 \\
\hline
\end{tabular}

Sumber : Hasil pengolahan kuisioner September 2015

Tabel 6. Distribusi Konsumen berdasarkan Saran yang Diberikan bagi RSUD Kota $\mathrm{X}$

\begin{tabular}{lrrrr}
\hline \multicolumn{1}{c}{ Saran } & \multicolumn{2}{c}{$\begin{array}{c}\text { Rawat Inap } \\
\text { (N=50) }\end{array}$} & \multicolumn{2}{c}{$\begin{array}{c}\text { Rawat Jalan } \\
(\mathbf{N = 3 9 2})\end{array}$} \\
\cline { 2 - 5 } & $\mathrm{n}$ & \multicolumn{1}{c}{$\%$} & $\mathrm{n}$ & \multicolumn{1}{c}{$\%$} \\
\hline $\begin{array}{l}\text { Penambahan, perbaikan fasilitas (AC/kipas angin, tempat } \\
\text { tidur pasien, penerangan, mushola) }\end{array}$ & 24 & 48,0 & 184 & 46,9 \\
$\begin{array}{l}\text { Peningkatan kebersihan (ruangan, kamar mandi) } \\
\text { Penambahan petugas (dokter, perawat) }\end{array}$ & 6 & 12,0 & 21 & 5,4 \\
$\begin{array}{l}\text { Keringanan biaya parkir } \\
\text { Peningkatan pelayanan (kecepatan, kedisiplinan, }\end{array}$ & 3 & 6,0 & 46 & 11,7 \\
keramahtamahan) & - & 4,0 & - & - \\
Kedatangan dokter diharapkan tepat waktu & - & - & 104 & 26,5 \\
Informasi dan alur berobat diharapkan lebih jelas & - & - & 26 & 6,6 \\
\hline
\end{tabular}

Sumber : Hasil pengolaan kuisioner September 2015

\section{PEMBAHASAN}

Kepuasan adalah tingkat keadaan yang dirasakan seseorang yang merupakan hasil dari mem-bandingkan penampilan atau outcome produk yang dirasakan dalam hubungannya dengan harapan seseorang (Kotler dan Amstrong, 2008). Kepuasan pasien/klien di rumah sakit merupakan hal yang penting bagi mutu pelayanan, karena akan memberikan informasi terhadap keberhasilan pemberi pelayanan. Persepsi pelanggan adalah salah satu faktor yang mempengaruhi kepuasan pelanggan terhadap kualitas jasa. Kepuasan pelanggan juga dipengaruhi oleh kualitas produk, harga, dan faktor-faktor pribadi lainnya seperti umur, jenis kelamin, pendidikan, status pekerjaan, serta yang bersifat situasi sesaat.
Beberapa alasan yang dikemukakan oleh Gerson (2004) mengapa harus mengukur mutu dan kepuasan pelanggan, diantaranya:

(1) mem-pelajari persepsi pelanggan;

(2) menentukan kebutuhan, keinginan,

(3) persyaratan dan harapan pelanggan;

(4) menutupi kesenjangan;

(5) me-meriksa apakah peningkatan mutu pelayanan dan kepuasan pelanggan sesuai harapan;

(6) pe-ningkatan kinerja akan berdampak pada pening-katan laba;

(7) mempelajari bagaimana perusa-haan melakukannya dan apa yang harus dilakukan kemudian; serta

(8) perbaikan berkesinambungan. Suatu perusahaan jasa diharapkan dapat melihat 
bagaimana kesan customer terhadap kualitas pelayanan yang diterima selama masa interaksi (Rabinowitz, 2006). Kesan tersebut dapat di-jadikan alat ukur terhadap gambaran kinerja dan penerimaan pelanggan terhadap perusahaan. Hal itu meliputi: weaknesses (apa yang dirasakan sebagai kelemahan perusahaan dalam pandangan pelanggan); strength (hal yang dirasakan sebagai kekuatan di mata pelanggan); serta area for improvement (hal yang dirasakan perlu untuk dilakukan perbaikan guna meningkatkan kinerja pelayanan).

Valuable customer adalah konsumen yang melalui word of mouth-nya dapat mendatangkan konsumen yang paling menguntungkan, dengan mengesampingkan seberapa banyak yang mereka beli untuk dirinya (Kumar, Petersen dan Leone, 2007). Konsumen siap menginformasikan mengenai apa yang mereka rasakan kepada orang lain terkait dengan suatu perusahaan. Solomon (2009) menyatakan word of mouth sebagai alih informasi tentang produk/jasa yang disampaikan oleh konsumen kepada konsumen lain dalam lingkungan non formal, terjadi tanpa sengaja dan sering kali melalui pembicaraan, diskusi, dan lainnya. Pengalaman berinteraksi seorang customer terhadap sebuah perusahaan diharapkan dapat menciptakan positive word of mouth, sehingga perusahaan dipersepsikan akan memiliki reputasi baik. Untuk membuktikan apakah perusahaan memiliki reputasi baik atau tidak, dapat diukur dengan indikator bahwa perusahan tersebut mampu memberikan kepuasan terhadap customernya, melalui rekomendasi pelanggannya.

Pengukuran tingkat kepuasan pelanggan dapat dilakukan dengan berbagai cara (Kotler dan Amstrong, 2008) antara lain: (1) Sistem keluhan dan saran, dimana konsumen diberikan kesempatan untuk menyampaikan keluhan dan saran mereka melalui menyediakan kotak saran, customer hotline, dan lain-lain; (2) Ghost shopping, merupakan salah satu cara untuk memperoleh informasi kepuasan klien dengan mempeker-jakan beberapa orang untuk berperan sebagai pembeli untuk melaporkan temuantemuannya mengenai kekuatan dan kelemahan produk pesaing; (3) Lost customer analysis, dilakukan dengan cara menghubungi pelanggan yang berhenti berlangganan dan memahami mengapa hal tersebut terjadi. Peningkatan lost customer rate menunjukkan kegagalan perusahaan untuk memuaskan pelanggan; (4) Survei kepuasan pelanggan, dimana diharapkan dapat diperoleh umpan masukan langsung dari pelanggan.

Net Promoter Score (selanjutnya disingkat dengan NPS) merupakan sebuah alat dan konsep kepuasan pelanggan yang dipublikasikan oleh Fred Reichheld, diperkenalkan pada tahun 2003 melalui artikelnya di Harvard Business Review yang berjudul "The One Number You Need to Grow” (Reichheld, 2011). Reichheld (2011) menyatakan bahwa metode NPS membagi obyek, baik konsumen ataupun pegawainya ke dalam tiga tipe, yaitu: (1) promoters (skor 9-10) merupakan konsu- 
men yang loyal, sangat antusias, mempromosikan gambaran yang sangat baik tentang peru-sahaan; (2) pasif (skor 7-8) merupakan konsu-men puas namun tidak terlalu loyal, sensitif terhadap harga, tidak memiliki hubungan yang kuat dengan perusahaan; dan (3) detractors (skor 0-6) merupakan konsumen yang tidak bahagia, memiliki citra yang buruk terhadap perusahaan, yang dapat menyebarkannya melalui ucapan/perkataan mereka.

Dengan bertanya satu pertanyaan sederhana: "Seberapa besar nilai rekomendasi saudara akan perusahaan ini kepada teman atau keluarga atau orang lain?”, perusahaan dapat mengetahui performance perusahaan dalam pandangan konsumen/pelanggan mereka, dimana respons pelanggan akan diukur dari angka $0-10$ (The Net Promoter Community, 2015).

Nilai NPS yang tinggi tentulah lebih baik dibandingkan dengan nilai NPS rendah. Nilai NPS yang tinggi memperlihatkan bahwa profil konsumen lebih banyak yang dikategorikan sebagai promoters dibandingkan dengan detractors. Hasil perhitungan NPS akan memberikan umpan balik perusahaan berdasarkan perspektif pelanggan mereka yang didasari oleh pengalamannya. Perusahaan diharapkan akan melakukan upaya perbaikan dalam pelayanan (The Net Promoter Community, 2015).

\section{PENUTUP}

\section{Simpulan}

Rata-rata usia responden 43,60 tahun.
Mayoritas berjenis kelamin perempuan, berpendidikan SMA dan pasien BPJS Kesehatan. Rata-rata nilai NPS pasien/keluarga adalah 6,68, dimana mayoritas responden memiliki profil sebagai konsumen detractors. Kelemahan RSUD Kota $\mathrm{X}$ dalam pemberian pelayanan di rawat inap adalah ketersediaan fasilitas (mushola, ac, kipas angin, penerangan ruangan) dan kebersihan (ruangan, kamar mandi). Kelemahan pelayanan di rawat jalan adalah sistem antrean yang dirasakan lama, ketersediaan fasilitas (mushola, ac, kipas angin, penerangan ruangan), kurang jelasnya informasi dan alur berobat, dan kebersihan (ruangan, kamar mandi). Kekuatan RSUD Kota X dalam pemberian pelayanan di rawat inap adalah keramahan petugas (dokter, perawat, administrasi) dan kecepatan layanan BPJS, serta pelayanan yang baik. Kekuatan pemberian pelayanan di rawat jalan adalah keramahan petugas (dokter, perawat, administrasi) dan pelayanan yang baik. Penambahan fasilitas rumah sakit merupakan saran yang mayoritas diberikan oleh konsumen baik di rawat inap maupun rawat jalan. Selanjutnya bagi konsumen rawat inap dua hal utama yang perlu diperhatikan adalah peningkatan kebersihan dan penambahan petugas. Bagi konsumen rawat jalan dua hal utama lain yang perlu menjadi perhatian adalah peningkatan pelayanan dan penambahan petugas.

\section{Saran}

Berdasarkan kesimpulan yang diperoleh, 
dibutuhkan upaya untuk meningkatkan nilai NPS konsumen sehingga diharapkan profil konsumen RSUD Kota X akan menjadi promoters (konsumen loyal yang akan antusias mempromosikan rumah sakit). Upaya tersebut antara lain penambahan fasilitas dan petugas (dokter/perawat) rumah sakit, peningkatan kebersihan dan pelayanan yang diberikan. Khusus bagi pelayanan di rawat jalan, sangat dibutuhkan upaya mengatasi antrean yang lama serta informasi alur berobat agar dapat lebih jelas. Hal ini dapat dilakukan melalui pemasangan poster alur berobat. Dibutuhkan pula upaya promosi kesehatan agar konsumen (pasien/keluarga) bersama-sama bertanggung jawab dalam menjaga kebersihan rumah sakit.

\section{Ucapan Terima Kasih}

Terima kasih kepada pihak RSUD Kota X dan Kantor Kesatuan Bangsa dan Politik (Kesbang-pol) Pemerintah Kota X, Sdr. Aufa dan Sdr. Zahra serta para pasien/keluarga RSUD Kota X.

\section{DAFTAR PUSTAKA}

Gerson R. F, 2004. Mengukur Kepuasan Pelanggan. Jakarta: Penerbit PPM.

Kotler, P. and Amstrong, G. 2008. Principle of Marketing. 12 $2^{\text {th }}$ edition. New Jersey: Pearson Education, Inc.

Kumar, Petersen and Leone. 2007. How Valuable Is Word of Mouth. Harvard Business Review.

Reichheld, F. 2011. Ultimate Question 2.0. Harvard Business Review Press.

Rabinowitz, K. 2006. Internal Customer Satisfaction Questionnaire. Proffesional Development Group, Inc.

Solomon, M.R. 2009. Consumer Behaviour: Buying, Having, and Being. 8th edition. New Jersey: Pearson Education.

The Net Promoter Community. 2015. Measu-ring your Net Promoter Score. http:// www.netpromotersystem.com/about/measuring-your-net-promoter-score.aspx. Diakses pada 25 Juni 2015. 